\title{
The Ultrastructure of the Gastric Mucosa in Normal and Hypophysectomized Rats ${ }^{1,2}$
}

\author{
RICHARD E. CORPRON ${ }^{3}$ \\ Department of Anatomy, The University of Michigan Medical School, \\ Ann Arbor, Michigan
}

\begin{abstract}
The objectives of this study were to observe with the electron microscope (a) the epithelial cell types found in the neck and isthmus of the gastric fundic gland of the rat, and (b) the effects of hypophysectomy on the gland. The following cell types were distinguished in the neck of the fundic gland of the rat: nondifferentiated cell, immature surface cell, mucous neck cell, and neck parietal cell. In the normal gland, these cell types resembled each other in the possession of a ground cytoplasm and nucleoplasm of low density, a poorly developed endoplasmic reticulum, few mitochondria and numerous free ribosomes. The most important structural difference between mucous neck and immature surface cells was the contrasting density of the secretory granules; both cell types differed from the nondifferentiated cell primarily in the presence of their characteristic secretory granules. The neck parietal cell appeared to be a developmental form between the immature surface cell and the mature parietal cell. No changes were observed in these cells to result from hypophysectomy.

Hypophysectomy caused marked involutional changes in the chief cell which involved mainly the organelles most directly concerned with protein synthesis, i.e., the ergastoplasm and Golgi apparatus. These effects were correlated with the loss of basophilia and secretory granules and with the reduction in cell size and capacity to secrete pepsinogen which were described previously. In contrast, the parietal cell, which is concerned with electrolyte transport, was affected much less.
\end{abstract}

The extensive literature dealing with the ultrastructure of gastric epithelial cells has been summarized by Kurosumi (' 61 ), Helander ('62) and Sedar ('64). General agreement exists concerning most of the ultrastructural characteristics of the chief, argyrophilic, parietal and surface mucous cells. However, much conflict revolves around the fine structure and interrelations of the cell types found in the neck of the gland and deep portion of the pit.

It is not agreed that a mucous neck cell can be differentiated with the electron microscope. Lillibridge ('64) working with man and Helander ('62) with the mouse were unsuccessful in their attempts to do so. Helander discounted the earlier identification and descriptions of mucous neck cells in the rat by Kurosumi et al. ('58) and Shibasaki ('61) on the grounds of poor fixation. The mucous neck cell as described by Sedar ('64) in the dog bears only a superficial resemblance to that illustrated by Ito and Winchester ('63) for the bat. Only Shibasaki ('61) has dealt with the possible existence of a nondifferentiated cell. Furthermore, only Lawn ('60) has noted the striking structural differ- ences between some parietal cells located in the neck as compared with those deeper in the gland. The first objective of this investigation was to acquire information concerning the ultrastructure of the cell types found in the neck region of the fundic gland.

A second objective was to observe the influence of hypophysectomy on the fine structure of chief and parietal cells. As observed with the light microscope, pituitary ablation in the rat caused a profound involution of chief cells accompanied by a decrease in cytoplasmic basophilia, number of zymogenic granules, and capacity to secrete pepsinogen (Baker and Abrams, '54). These changes were evident within three days after the operation. To a less significant degree parietal cells were somewhat smaller and contained fewer mitochondria (Baker and Abrams, '54; Baker and Clark, '61). The $\mathrm{pH}$ of the gastric juice was elevated and total acidity reduced (Crafts and Walker, '47). It is im-

\footnotetext{
1 Supported in part by research grants from the ISPHS (AM-00131-13) and The Upjohn Company. 2 From a thesis submitted in partial fulfillment of the requirements for the Doctor of Philosophy degree in Anatomy, University of Michigan.

3 Present address: School of Dentistry, University of Michigan, Ann Arbor.
} 
portant to know how these modifications are reflected at the ultrastructural level.

\section{MATERIALS AND METHODS}

Twelve young adult female white rats of the Sprague-Dawley strain were used. One member of each of the six pairs was hypophysectomized by the parapharyngeal approach and the other served as a control. The control animal was pair-fed against the hypophysectomized rat for 2-7 months following the operation. The diet consisted of Purina Laboratory Chow. Prior to termination of the experiment, the rats were starved for 18 hours. The mean initial and final body weights for the nonhypophysectomized rats were $193 \pm$ standard deviation $9 \mathrm{gm}$ and $252 \pm 6 \mathrm{gm}$, respectively, and for the hypophysectomized rats, $188 \pm 17 \mathrm{gm}$ and $176 \pm 5 \mathrm{gm}$, respectively. Completeness of pituitary removal was verified by loss of body weight and by microscopic examination of the serially sectioned pituitary capsules.

The stomach was removed while the rat was under sodium amytal anesthesia. It was incised along the lesser curvature from the pyloroduodenal junction to the cardiac orifice and the luminal contents were washed out with $0.9 \% \mathrm{NaCl}$ solution. The stomach was pinned out flat on a cork block and the mucosal surface flooded with several drops of fixative. Twelve to 16 pieces of mucosa measuring $1 \mathrm{~mm}^{3}$ were taken from the greater curvature approximately half-way between the horizontal ridge and the pyloric opening.

Tissues from five pairs of rats were fixed for two hours at $4^{\circ} \mathrm{C}$ in $1 \%$ osmic acid buffered with Veronal acetate to $\mathrm{pH}$ 7.4 (Palade, '52). Tissues from one pair of rats were fixed in Dalton's fluid (Dalton, '55) at $\mathrm{pH} 7.2$ for two hours at $4^{\circ} \mathrm{C}$. Subsequently, the tissues were dehydrated in ethanol and propylene oxide prior to embedding in Epon 812 ( $50 \%$ mixture A: $50 \%$ mixture B) according to Luft ('61). Sections from 8 to 10 blocks per animal were cut on a Porter-Blum microtome, mounted on grids covered with carboncoated Formvar films. They were stained with $2 \%$ uranyl acetate for 2 to 4 hours (Watson, '58). The sections were photographed with an RCA EMU-3D electron microscope at an accelerating voltage of
$50 \mathrm{KV}$, with a $25 \mu$ objective aperture. Approximately 2,000 electron micrographs were taken at original magnifications of 1,400 to 42,000 .

\section{OBSERVATIONS}

\section{Epithelial cells of normal rats}

Nondifferentiated cell. The nondifferentiated cell (fig. 2) was columnar and often slightly wider at the base than at the apex. The lateral plasmalemma was usually quite straight with only occasional interdigitations with contiguous cells. Desmosomes were observed occasionally. The basal plasmalemma was straight. Stubby microvilli projected from the apical surface. The nucleus was oval or of irregular shape and contained a nucleolus and nucleoplasm of low density.

Other features were especially distinctive. The cytoplasm was much less dense than that of neighboring parietal cells (fig. 2). The endoplasmic reticulum was poorly developed; its outer surface was sometimes smooth with ribosomes being attached in only restricted areas (fig. 3). The cisternae contained a substance of moderate density. Clusters of free ribosomes were distributed throughout the cytoplasm. Components of the Golgi apparatus were distributed widely through the perinuclear cytoplasm, being found lateral and even basal to the nucleus. The Golgi apparatus consisted of indistinct flattened saccules, small Golgi vesicles and occasional vacuoles. Little dilation of the Golgi cisternae was observed. Although the cell illustrated in figure 2 contained bodies which may have been secretory granules, other nondifferentiated cells were observed which did not contain these questionable inclusions.

Surface mucous cell. The ultrastructure of the surface mucous cell in the rat has been described in detail by Kurosumi ('61). My report is concerned only with observations which are new or different from those of Kurosumi and other workers. The Golgi apparatus formed a high cap over the nucleus and extended laterally to occupy much of the supranuclear cytoplasm (fig. 4). The peripheral portion of the Golgi apparatus was composed of stacks of 4 to 5 flattened saccules and a multitude of Golgi vesicles which accumu- 
lated chiefly at the ends of and inside the saccules. Only the external cisternae showed slight dilation. A unique feature of both Golgi saccules and vesicles was their high electron-scattering capacity.

Secretory granules were found usually within and superior to the Golgi apparatus. In contrast to the observation of Kurosumi ('61) the granules appearing within the Golgi apparatus were not of low density (fig. 4) but usually showed greater electron-scattering capacity than those in the apical cytoplasm. Each secretory granule was enclosed at least partially by a membrane. Thus, the secretory granules which were associated closely with the Golgi apparatus may be the counterpart of the Golgi vacuoles containing material of low density which are found in many other types of cells. Such vacuoles were never observed in the surface cell. The dense secretory granules varied in size and the smaller ones approximated the size of the Golgi vesicles but there was no clear evidence that secretory granules arose by simple enlargement of Golgi vesicles. The mucous granules appeared to stream out of the Golgi apparatus into the apical cytoplasm. In contrast to Kurosumi ('61) I saw no evidence of transformation of mitochondria to mucous granules.

An apical cytoplasmic zone containing mucous granules was unique in several respects. It was devoid of mitochondria and endoplasmic reticulum and its deeper portion contained only a few ribosomes. This apical, organelle-free cytoplasm was separated from subjacent cytoplasm by abundant fibrils which seemed to form an irregular transverse band across the cell and to be continuous with those emanating from desmosomes.

The endoplasmic reticulum was moderately well-developed and extended throughout the cytoplasm except for the apical zone. For the most part it possessed attached ribosomes. The cisternae were wide, tortuous, branched and contained material of moderate density. Clusters of free ribosomes were found throughout the cytoplasm.

In the neck region of the fundic gland, an immature form of the surface mucous cell was readily identified by means of the mucous granules of high density which appeared in the apical region (fig. 5). Except for this feature, the immature surface cell resembled the nondifferentiated cell with respect to shape, nuclear structure, extent and form of the endoplasmic reticulum, distribution and quantity of ribosomes, number and structure of mitochondria, and structure of the Golgi appartus.

Mucous neck cell. The mucous neck cell was distinguishable from other cell types by several distinctive structural characteristics as well as by the fact that it was located deeper in the gland than nondifferentiated and surface mucous cells. Kurosumi et al. ('58) described the mucous neck cell of the rat in considerable detail. However, my observations differ in many respects.

The mucous neck cell was high cuboidal (fig. 6) except when compressed basally by the pressure exerted by adjacent parietal cells. If filled with secretion, the apical surface bulged slightly into the glandular lumen. Only occasional short, rounded microvilli were observed on the surface and, if present, were located near the lateral junction with adjacent cells. The lateral plasmalemma was straight except for occasional interdigitations with contiguous cells. Desmosomes occurred along the apical one-third of the lateral plasmalemma inferior to the zonulae occludens and adherens. The nucleus filled much of the basal portion of the cell and tended to be flattened against the base. Its envelope was often deeply indented. There was little cytoplasm lateral and basal to the nucleus.

The round secretory granules differed distinctively from those of the surface cells and chief cells. The density of individual granules as well as that of the total population in a cell was remarkably uniform. The granules appeared finely granular in texture (fig. 6). The overlying dust-like particles described by Kurosumi et al. ('58) were not observed. The secretory granules were far less dense than those of the surface cells. Usually the secretory granules of chief cells were not well preserved. If they were preserved, their density was greater than that of the granules in mucous neck cells but less than that of the granules in surface cells. A clearly defined enveloping 
membrane was observed only around those granules in mucous neck cells which were located proximal to the Golgi apparatus (fig. 7). The periphery of the apical granules was less clearly defined, the granules often becoming confluent with one another. Apically they appeared to be released from the cell by dissolution of the overlying plasmalemma. Golgi vesicles were often in direct contact with the substance of the secretory granule (fig. 7). The significance of this relationship with respect to formation of secretion could not be ascertained. Contrary to Kurosumi et al. ('58), no "foaminess" at the periphery of the granules was observed; this condition must have resulted from inadequate preservation as he suspected.

The Golgi apparatus occupied the cytoplasm immediately superior to the nucleus and tended to spread across the cell (fig. 7). It did not extend into the apical cytoplasm between the granules. The Golgi apparatus consisted of stacks of flattened saccules, the cisternae of the external saccules exhibiting considerable dilation. Many dense vesicles were present at the ends of the saccules.

The rough-surfaced endoplasmic reticulum was poorly developed; it and free ribosomes were distributed throughout the cell, including the apical cytoplasm between secretory granules. Thus, the endoplasmic reticulum was not confined to the basal and peripheral cytoplasm as indicated by Kurosumi et al. ('58). The "general appearance" of the ergastoplasm was equated by Kurosumi et al. ('58) to that of the chief cells. In my material, there was a vast difference in degree of development.

A columnar cell believed to be an immature mucous neck cell was observed in the neck region of the fundic gland (fig. 8). It resembled the nondifferentiated cell with respect to the ultrastructure of the nucleus, mitochondria, ground cytoplasm, roughsurfaced endoplasmic reticulum, and in the number and distribution of free ribosomes. Differentiation of the cell toward the mucous neck cell was indicated by the development of apical granules, which on the basis of their density and structure resembled those of mature mucous neck cells.
Neck parietal cell. Lawn ('60) noted that neck parietal cells differ from those deeper in the gland (mature parietal cells) by having cytoplasm of less density, fewer cytoplasmic vacuoles, collapsed and less extensive intracellular canaliculi, more prominent rough-surfaced endoplasmic reticulum, and fewer and more scattered mitochondria. My observations reveal that mature and neck parietal cells may occur side by side in the neck, although the neck parietal cell is predominant. Neck parietal cells were never found in the fundus of the gland.

Most of the features cited by Lawn were confirmed. The following additional observations were made. The nucleus was spherical, basally located, and contained a nucleolus and ribosomes in low concentration (fig. 9). Rough-surfaced endoplasmic reticulum was sparsely distributed (figs. 5 and 9), being most common in the immediate perinuclear region. Clusters of ribosomes were scattered throughout the cytoplasm being quite sparse in the apical portion. Collapsed intracellular canaliculi extended as deeply as in the mature form of parietal cell (figs. 5 and 9 ), often nearly approximating the basal side of the cell. Microvilli were either long and of uniform density and width (fig. 10), or bulbous and with a less dense interior (fig. 5). Mitochondria varied in size, the maximum being considerably greater than that of mitchondria in the mature cell. They were pleomorphic and contained densely packed, delicate cristae and a matrix of low density. The peripherally located Golgi apparatus was made up of stacks of flattened saccules with little dilation of the cisternae, no vacuoles and few vesicles (fig. 10). Cytoplasmic vacuoles, if present at all, were restricted to the apical and pericanalicular region, were usually collapsed, and possessed a dense outer membrane. Multivesicular bodies were present. Granules having the density and size of the secretory granules in surface mucous cells were identified in the cytoplasm of some cells (figs. 9 and 10).

\section{The effects of hypophysectomy}

No significant changes were observed after hypophysectomy in the mucous neck, nondifferentiated, surface and neck parie- 
tal cells. However, ultrastructural changes did occur in the chief and mature parietal cells. Since the structure of each cell type varied somewhat in the control rats, particularly in relation to its position in the gland, it was necessary to study many cells in each case and to insure that the cells compared in control and hypophysectomized. rats were located at approximately the same levels in the gland.

Chief cell. The following evaluations are based only on observation of chief cells located in the fundus of the gland, this level being identified by the presence of argyrophilic cells and the dominance of chief over parietal cells. After hypophysectomy, chief cells were uniformly smaller (fig. 12) than those of the controls (fig. 11) and their form was altered. While most cells in the controls were columnar and possessed a granule-filled apical cytoplasm which bulged into the glandular lumen, after pituitary ablation the cells were lower and usually had a flat apex.

The technical methods employed did not preserve the large pepsinogen granules regularly. The number of granules could be evaluated, however, by the vacuoles left following their dissolution. In all six hypophysectomized rats, the maximal number observed in any cell and the overall average number per cell were less than in the controls. In one control rat, numerous chief cells contained few granules. Nevertheless, those of the paired hypophysectomized rat were also poorly granulated. Concurrently with fall in quantity of granules the volume of apical cytoplasm also became less.

With depletion of the large secretory granules, a zone of cytoplasm appeared beneath the apical plasmalemma (figs. 14 and 15) from which these granules were absent. Most superficially, no organelles could be seen. Small dense granules (fig. 11) with smooth dense outer membranes and measuring $0.07-0.20 \mu$ in diameter were present in the nonhypophysectomized rats. In density, the small granules resembled Golgi vesicles and granules of sizes transitional between the two were observed commonly. After hypophysectomy they became relatively more prominent although probably not increased in absolute number (fig. 15). Thus, the small granules did not share in the regression which engulfed the large granules after hypophysectomy.

As compared with nonhypophysectomized rats, the average amount of ergastoplasm ${ }^{4}$ was less in the chief cells of the hypophysectomized member of the five pairs in which this comparison could be made with certainty (figs. 11 and 12). This involved in most cells a reduction in density of the ground cytoplasm, usually in the number of ribosomes, and often in the extent of the endoplasmic reticulum. These changes were demonstrated after fixation in buffered osmic acid (figs. 16 and 17) and Dalton's fluid (figs. 18 and 19). Polyribosomes (fig. 13) occurred in both control and operated rats, especially in the perinuclear area. In 4 of 5 hypophysectomized rats they appeared to be increased in frequency but this observation could not be verified with certainty.

The Golgi apparatus was affected severely by hypophysectomy. The supranuclear position of the Golgi apparatus was maintained, but its extent in the cell was reduced so that it became more compact (figs. 20 and 21). Overall dilation of Golgi cisternae was usually reduced; some large vacuoles were retained. Golgi vesicles remained prominent and no alteration in their number or structure could be ascertained.

Except for a possible increase in the irregularity of the nuclear envelope, hyphysectomy caused no changes in the structure of the nucleus, nucleolus or mitochondria (figs. 16 and 17). Possible change in size of the nucleus was not accurately evaluated.

Parietal cell. In evaluating the parietal cell, comparisons were made only between cells located in the body or fundus of the gastric gland in order to avoid the confusion which would be created by consideration of the neck parietal cell. Cellular size was reduced. For evaluation of canaliculi, satisfactory micrographs were available from

4 "Ergastoplasm" is used to encompass endoplasmic reticulum with its cisternae, the accompanyin attached and free ribosomes and intervening attached and free ribosomes and intervening ground
cytoplasm. The term is applied to those cytoplasmic areas where the endoplasmic reticulum is quite concentrated. This ultrastructure generally characterizes basophilic cytoplasm as seen with the light microscope. Since "ergastoplasm" was applied originally to such areas, extension of its use to electron micrograph seems appropriate. 
four nonhypophysectomized and from four hypophysectomized rats. In all of the latter the maximal caliber of the intracellular canaliculi was reduced by hypophysectomy so that the lumen was often nearly occluded by the microvilli (figs. 22 and 23 ). In contrast to the rather regular form and uniform caliber of intracellular microvilli in nonhypophysectomized rats, the microvilli after hypophysectomy were greatly distorted. No significant alteration was observed in number of cytoplasmic vacuoles, mitochondria and microvilli, nor in the ultrastructure of the nucleus, Golgi apparatus or mitochondria.

\section{DISCUSSION}

\section{The normal gland}

The observations presented show that the epithelial cells in the neck of the fundic gland may be differentiated into several closely related types on the basis of their ultrastructure.

Nondifferentiated cell. Most primitive cells when examined with the electron microscope have been distinguished by a paucity of endoplasmic reticulum, few mitochondria, and a ground cytoplasm and nucleoplasm of low density (Han, '61). The nondifferentiated cell of the gastric gland possesses similar characteristics. However, it also contains numerous free ribosomes and a well-developed Golgi apparatus.

Mucous neck cell. There can be little doubt that the mucous neck cell exists as a distinctive cell type in the rat and that its structural characteristics are as distinctive when viewed with the electron microscope as they are when observed with the light microscope. With the exceptions and additions already cited, the descriptions of Kurosumi et al. ('58) and Shibasaki ('61) were supported by my observations. The mucous neck cell of the rat resembles closely that of the bat as described by Ito and Winchester ('63). In the rat, the following minor differences are evident: fewer apical microvilli, the limitation of secretory granules to the supranuclear cytoplasm, and the absence of enveloping membranes around the apical secretory granules. In both rat and bat, secretory granules are of remarkable uniformity in density and are considerably less dense than those of the surface cells. On the other hand in the mucous neck cell of the dog, as illustrated by Sedar ('64), the secretory granules are as dense as those in the surface cell.

The failure of Helander ('62) in the mouse and Lillibridge ('64) in man to delimit a mucous neck cell is difficult to understand since in both species such distinctions can be made with the light microscope. The mucous neck cells of the rat show some similarities to the "mucoid" cells as illustrated by Helander ('62) for the mouse but can hardly be equated with them.

The morphological involvement of the Golgi apparatus in the elaboration of secretion by the mucous neck cell was not clarified. Fully formed secretory granules were present adjacent to the Golgi apparatus; no Golgi vacuoles containing secretion of lower density, as is observed frequently in the pancreas, were seen. No transitional stages between the contents of Golgi cisternae and secretory granules nor between Golgi vesicles and granules were observed even though the vesicles were often in direct contact with the substance of the granule.

Surface mucous cell. The immature surface cell is almost identical in its ultrastructure to the nondifferentiated cell except for the presence of dense spherical mucous droplets in its apical cytoplasm. Maturation of the immature surface cell as it moves into the wall of the gastric pit is accompanied by many changes (figs. 4 and 5). Cytoplasm above the nucleus expands greatly and becomes delineated into a region proximal to the nucleus which contains organelles, and into an apical organelle-free zone which is utilized for storage of the secretory product. These regions are separated by intracytoplasmic filaments. During maturation of the cell, endoplasmic reticulum undergoes considerable expansion and ribosomes increase in number. The Golgi apparatus enlarges, becomes more complex and assumes a supranuclear position; the electron-scattering capacity of the flattened saccules and vesicles increases.

The presence of mucous droplets in the cytoplasmic area surrounded by the Golgi 
apparatus strongly suggests a direct involvement of this organelle in their formation. Although others (Kurosumi et al., '58; Ito and Winchester, '63) have observed smaller granules of less density in the Golgi apparatus and interpreted them to represent stages in formation of secretion, the precise manner in which the Golgi apparatus is involved in synthesis of secretion was not revealed in my preparations. In view of the high electron-scattering capacity of the granules, it is particularly significant that the stacks of flattened saccules exhibit a similar property far in excess of that seen in the Golgi appartus of most other cells in the body. Thus, the synthesis of mucus in association with these membranes is suggested. Indeed, the addition of carbohydrate to protein in Golgi vacuoles of mucus-secreting cells is indicated by the concentration of radioactivity therein following the administration of $\mathrm{S}^{35} \mathrm{O}_{4}$ (Lane et al., '64) or of $\mathrm{H}^{3}$ labeled glucose (Peterson-Neutra, '65).

Neck parietal cell. Of the many workers who have examined the gastric mucosa with the electron microscope only Lawn ('60) appreciated the existence of two distinctive forms of parietal cells. As suggested by Lawn, the neck parietal cell is most likely an immature stage in formation of the parietal cell. This conclusion may be supported by the low density of the ground cytoplasm and nucleoplasm; the varied form, size, and densely packed, delicate cristae of the mitochondria; and the poorly developed endoplasmic reticulum. The neck parietal cell occurs only in the superficial region of the gland; the more typical mature form is located in the body and fundic region and frequently in the neck as well.

The application of the electron microscope to experimental studies of the parietal cells in rats requires recognition of the existence of the neck parietal cell. Valid comparisons between parietal cells in control and treated rats can be made only at comparable levels in the gland. Although the occurrence of a neck parietal cell is yet to be demonstrated in other species its possible presence was not considered by Sedar and Friedman ('61) in their experimental studies on the parietal cell of the dog nor by Ito ('61) in his study of many species including the rat. Ito concluded that the appearance of cytoplasmic vacuoles is a product of the action of technical factors on a tubular endoplasmic reticulum. Two of the cells illustrated by Ito ('61) (figs. 1 and 6) on which he based his conclusions, were located high in the mucosa because surface cells were shown adjacent to them. Sedar ('62) concurred with Ito's view with respect to the frog.

Cell relationships. There are numerous close ultrastructural similarities between the nondifferentiated, immature surface, immature mucous neck and neck parietal cells. These include the low density of the ground cytoplasm and nucleoplasm, poor development of the endoplasmic reticulum to which are attached only occasional ribosomes, and the presence of numerous free ribosomes. The only feature which differentiates the immature surface cell from the nondifferentiated cell is the presence of apical mucous granules. Indeed, clearly defined nondifferentiated cells lacking in these dense granules are uncommon. The immature mucous neck cell is distinguished by the large size and moderate density of its secretory granules. The neck parietal cell, however, possesses many distinctive characteristics.

General agreement exists concerning the following aspects of the developmental interrelationships of cells in the gastric

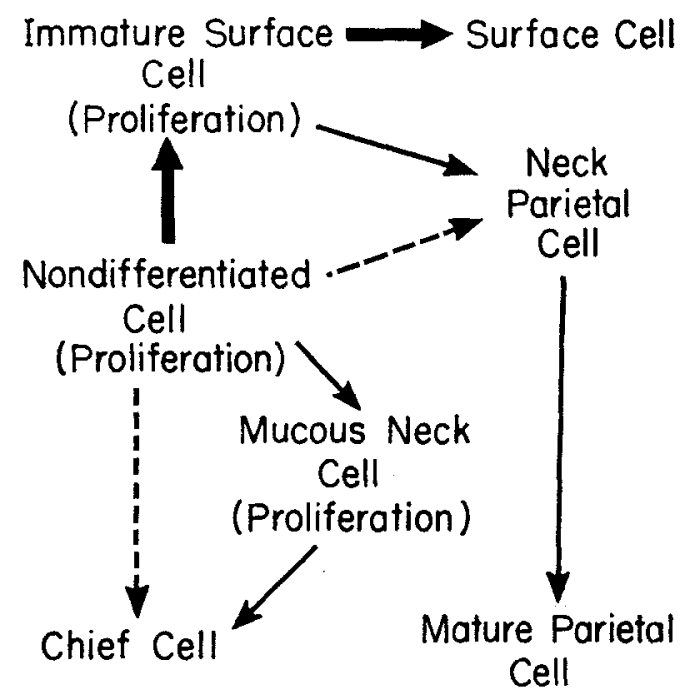

Figure 1 
gland. (1) Chief and parietal cells rarely divide by mitosis. (2) Proliferation of cells occurrs in the neck of the gland and involves mucous neck and immature surface cells (Stevens and Leblond, '53; Leblond and Walker, '56). (3) Immature surface cells undergo maturation and glide up onto the surface of the mucosa from whence they are sloughed into the lumen (Stevens and Leblond, '53; Leblond and Walker, '56; Messier, '60).

On the other points there is strong disagreement. In dispute is the possibility that chief and parietal cells are replaced. Messier ('60) concluded from studies utilizing labeling with $\mathrm{H}^{3}$-thymidine that chief and parietal cells are not formed by transformation of mucoid cells which divide in the neck. Myhre (60) and Hunt and Hunt ('62) came to the opposite conclusion and further showed that following stimulation of the mucosa the label, which at first appears over mucous neck cells, later is found deeper in the gland over chief and parietal cells indicating transformation of mucous neck cells to the other two types. Townsend ('61) demonstrated the apparent transformation of mucous neck cells to chief cells and of mucus-containing cells to parietal cells by histochemical methods in both normal and regenerating gastric mucosa.

With respect to the origin of the chief cell my observations are not helpful. But the origin of the parietal cell from the immature surface cell is suggested by the presence of dense mucous granules in the neck parietal cell. The occurrence of mucus in the apex of transforming parietal cells was described by Townsend ('61) utilizing the light microscope; he inferred that these apical portions are sloughed into the glandular lumen. My observations further indicate that the neck parietal cell represents a stage in the development of the mature parietal cell from the immature surface cell. Maturation of the parietal cell would then involve an increase in density of the cytoplasm, reduction in average size of the mitochondria, appearance of a canalicular lumen, a reduction in caliber of the microvilli, and appearance of cytoplasmic vacuoles or a tubular system. The origin of the mucous neck cell from the nondifferentiated cell seems clear. In no case was an interdevelopmental relationship between mucous neck cell and immature surface cell indicated by the presence within a single cell of the distinctive secretory granules characteristic of each cell type although transformation of surface cells to mucous neck cells has been described in a study utilizing the light microscope (Hunt, '58). The probable cellular relationships are summarized in figure 1 .

\section{The effects of hypophysectomy}

Most experimental studies in which the electron microscope has been used have been characterized by a general lack of attention to the reproducibility of the observations being reported. Without such information the reliability of the observations can hardly be ascertained. In my study an attempt was made to alleviate this deficiency by the preservation of multiple blocks of tissue obtained from a carefully specified area of the mucosa, by thorough examination of the ultrastructure of cells at various levels of the mucosa, and by photographing a large number of cells in order to be certain that the differences described between control and hypophysectomized rats were regular in their appearance. When a response was observed in only a portion of the hypophy. sectomized rats, this information is given.

Chief cell. The ultrastructural changes observed after hypophysectomy in the chief cell confirm the observations of Baker and Abrams ('54) with respect to reduction in size of the cell and depletion of zymogenic granules from the apical cytoplasm. Since the secretory product, pepsinogen, is a protein and a host of biochemical (Hultin, '64) and structural investigations (Siekevitz and Palade, '59; Dalton, '61; Caro, '61; Caro and Palade, '64) have demonstrated the involvement of ergastoplasm and Golgi apparatus in protein synthesis, the changes induced in these cellular components by hypophysectomy are especially pertinent. The marked loss of cytoplasmic basophilia which follows pituitary ablation (Baker and Abrams, '54) indicates a reduction in the amount of ribonucleic acid (RNA) contained in the cell. Since the RNA fraction which accounts for basophilia is unknown, it is especially important that in my study a loss 
of ribosomes was observed after hypophysectomy. In addition, the reduction in extent of the endoplasmic reticulum and in the density of the ground cytoplasm shows that the structures which appear to be involved in peptide synthesis (Caro and Palade, '64; Hultin, '64) undergo change upon withdrawal of pituitary hormones.

The possible involvement of technical deficiencies in the induction of the ergastoplasmic changes observed after hypophysectomy merits consideration since somewhat similar characteristics in other cells are occasionally attributed to the influence of faulty fixation or embedding. Hypophysectomy may have altered the tissue in such a way that cytoplasm could not be preserved in the usual manner. The regularity in the appearance of the changes described in endoplasmic reticulum and in the ground cytoplasm of different cells of the hypophysectomized rats, their rareness in the controls, their demonstrableness with two different fixatives, and adequate fixation of other adjacent cell types, all indicate that hypophysectomy was either directly or indirectly responsible for the observations described. Helander ('64) reported alterations of the endoplasmic reticulum and ribosomes, as well as the Golgi apparatus, following refeeding of the starved mouse.

Polyribosomes (Rich et al., '63) were observed occasionally in the perinuclear area of control rats. A chain was composed of as many at 16 ribosomes. In more than half of the hypophysectomized rats polyribosomes appeared to be increased in number but the regularity of response could not be established. Biochemical studies of polyribosomes (Rich et al., '63), their depletion from fibroblasts in scorbutic guinea pigs and restoration following treatment with ascorbic acid (Ross and Benditt, '64) lead one to associate the presence of polyribosomes with active protein synthesis. Thus, an increase in number of polyribosomes in chief cells at a time of depressed protein synthesis cannot be explained.

In glandular cells a direct relationship between size of Golgi apparatus and secretory activity appears to exist (Kirkman and Severinghaus, '38; Dalton, '61). With the reduction in secretory activity which occurs in chief cells after hypophysectomy the Golgi apparatus becomes smaller and more compact. However, no alteration in number of saccules, vesicles or vacuoles is evident although an overall reduction in dilation of the saccular cisternae appears to be present. The apparent "budding off" of vesicles from the endoplasmic reticulum and their subsequent fusion with Golgi saccules, as postulated by Zeigel and Dalton ('62) and Essner and Novikoff ('62) was rarely observed in the granulated chief cell of both nonhyophysectomized and hypophysectomized rats.

In view of the evidence that chief cells may secrete intrinsic factor (Boass and Wilson, '64) as well as pepsinogen, the appearance within the cell of each secretion in a different morphological form must be considered. It is possible that the dense granule represents a second secretion and its failure to regress following hypophysectomy suggests a different response to pituitary hormones. Also, because of its size and ultrastructural characteristics the small granule may be identical to the microbody of Rouiller and Bernhard ('56) and the lysosome of de Duve ('59).

Parietal cell. The influence of hypophysectomy on the parietal cell as observed with the light microscope (Baker and Abrams, '54) was far less pronounced than on the chief cell. Similarly, the production of hydrochloric acid (Crafts and Walker, '47) was affected much less than the secretion of pepsinogen (Baker and Abrams, '54). Pituitary ablation induced little change in the ultrastructure of the parietal cell, this being limited to reduced canalicular caliber and distortion of microvilli. Little is known of the role of cell structures in secretion of hydrochloric acid so meaningful interpretation is not possible.

Modification of the canaliculi and associated microvilli have been observed under other experimental conditions. Vial and Orrego ('60) and Sedar and Friedman ('61) noted that canaliculi and the surface area of their microvilli were increased in stomachs stimulated by several experimental means. Following the claim of Ito ('61) that patency of canaliculi cannot be correlated with the physiological state of 
the animal because of the great normal variation, Sedar ('62) appears to have questioned his earlier results. Although considerable variation in width of the canaliculi does exist, my observations indicate that one can detect differences in their average caliber following subjection of the rat to experimental procedures providing careful attention is given to the level of the cell in the gland and an adequate sampling is effected.

\section{ACKNOWLEDGMENT}

I wish to thank Dr. Burton L. Baker for his guidance during this study.

\section{LITERATURE CITED}

Baker, B. L., and G. D. Abrams 1954 Effect of hypophysectomy on the cytology of the fundic glands of the stomach and on the secretion of pepsin. Amer. J. Physiol., 177: 409-412.

Baker, B. L., and R. H. Clark 1961 Influence of hypophysectomy on oxidative enzymes and size of parietal cells in gastric mucosa. Proc. Soc. Exp. Biol. Med., 106: 65-67.

Boass, A., and T. H. Wilson 1964 Cellular localization of gastric intrinsic factor in the rat. Am. J. Physiol., 206: 783-786.

Caro, L. G. 1961 Electron microscopic radioautography of thin sections: The Golgi zone as a site of protein concentration in pancreatic acinar cells. J. Biophys. Biochem. Cytol., 10: $37-46$.

Caro, L. G., and G. E. Palade 1964 Protein synthesis, storage, and discharge in the pancreatic exocrine cell. An autoradiographic study. J. Cell Biol., 20: 473-495.

Crafts, R. C., and B. S. Walker 1947 The effects of hypophysectomy on gastric acidity of adult female rats. Endocrinology, 40: 395-402.

Dalton, A. J. 1955 A chrome-osmium fixative for electron microscopy. Anat. Rec., 121: 281. Abstr.

1961 Golgi apparatus and secretion granules. In: The Cell. J. Brachet and A. E. Mirsky (ed.), Academic Press, New York, vol. II, pp. 603-619.

de Duve, C. 1959 Lysosomes, a new group of cytoplasmic particles. In: Subcellular Particles. T. Hayashi (ed.), The Ronald Press Co., New York, pp. 128-159.

Essner, E., and A. B. Novikoff 1962 Cytological studies on two functional hepatomas. Interrelations of endoplasmic reticulum, Golgi apparatus, and lysosomes. J. Cell Biol., 15: 289-312.

Han, S. S. 1961 The ultrastructure of the mesenteric lymph node of the rat. Am. J. Anat., 109: 183-225.

Helander, H. F. 1962 Ultrastructure of fundus glands of the mouse gastric mucosa. J. Ultrastructure Res., suppl. 4: 1-123.

1964 Ultrastructure of gastric fundus glands of refed mice. J. Ultrastructure Res., 10: $160-175$.
Hultin, T. 1964 Ribosomal functions related to protein synthesis. In: International Review of Cytology. G. H. Bourne and J. F. Danielli (ed)., Academic Press, New York and London, vol. 16 , pp. $1-36$.

Hunt, T. E. 1958 Regeneration of the gastric mucosa in the rat. Anat. Rec., 131: 193-212.

Hunt, T. E., and E. A. Hunt 1962 Radioautographic study of proliferation in the stomach of the rat using thymidine- $\mathrm{H}^{3}$ and compound 48/80. Anat. Rec., 142: 505-517.

Ito, S. 1961 The endoplasmic reticulum of gastric parietal cells. J. Biophys. Biochem. Cytol., 11: 333-347.

Ito, S., and R. J. Winchester 1963 The fine structure of the gastric mucosa in the bat. J. Cell Biol., 16: 541-577.

Kirkman, H., and A. E. Severinghaus 1938 A review of the Golgi apparatus. Part III. Anat. Rec., 71: 79-103.

Kurosumi, K. 1961 Electron microscopic analysis of the secretion mechanism. In: International Review of Cytology. G. H. Bourne and J. F. Danielli (ed.), Academic Press, New York, vol. 11, pp. 1-124.

Kurosumi, K., S. Shibasaki, G. Uchida and Y. Tanaka 1958 Electron microscope studies on the gastric mucosa of normal rats. Arch. Histol. Jap., 15: 587-624.

Lane, N., L. G. Caro, L. R. Otero-Vilardebó and G. C. Godman 1964 On the site of sulfation in colonic goblet cells. J. Cell Biol, 21: 339351.

Lawn, A. M. 1960 Observations on the fine structure of the gastric parietal cell of the rat. J. Biophys. Biochem. Cytol., 7: 161-166.

Leblond, C. P., and B. E. Walker 1956 Renewal of cell populations. Physiol. Rev., 36: 255-276.

Lillibridge, C. B. 1964 The fine structure of normal human gastric mucosa. Gastroenterology, 47: 269-290.

Luft, J. H. 1961 Improvements in epoxy resin embedding methods. J. Biophys. Biochem. Cytol., 9: 409-414.

Messier, B. 1960 Radioautographic evidence for the renewal of the mucous cells in the gastric mucousa of the rat. Anat. Rec., 136: 242. Abstr.

Myhre, E. 1960 Regeneration of the fundic mucosa in rats: $V$. An autoradiographic study on the effect of cortisone. Arch. Path., 70: $476-485$.

Palade, G. E. 1952 A study of fixation for electron microscopy. J. Exp. Med., 95: 285-298.

Peterson-Neutra, M. 1965 Synthesis of complex carbohydrates in Golgi saccules: an electron microscope-radioautographic study. Anat. Rec., 151: 399. Abstr.

Rich, A., J. R. Warner and H. M. Goodman 1963 The structure and function of polyribosomes. Cold Spring Harbor Symposia on Quantitative Biology, 28: 269-285.

Ross, R. ,and E. P. Benditt 1964 Wound healing and collagen formation. IV. Distortion of ribosomal patterns of fibroblasts in scurvy. J. Cell Biol., 22: 365-390.

Rouiller, C., and W. Bernhard 1956 "Microbodies" and the problem of mitochondrial re. 
generation in liver cells. J. Biophys. Biochem. Cytol., 2 (suppl.): 355-360.

Sedar, A. W. 1962 Electron microscopy of the the oxyntic cell in the gastric glands of the bullfrog, Rana catesbiana. III. Permanganate fixation of the endoplasmic reticulum. J. Cell Biol., 14: 152-156.

1964 Stomach and intestinal mucosa. In: Electron Microscopic Anatomy. S. M. Kurtz (ed.), Academic Press, New York, pp. 123-148.

Sedar, A. W., and M. H. F. Friedman 1961 Correlation of the fine structure of the gastric parietal cell (dog) with functional activity of the stomach. J. Biophys. Biochem. Cytol., 11: 349-363.

Shibasaki, S. 1961 Experimental cytological and electron microscope studies on the rat gastric mucosa. Arch. Histol. Jap., 21: 251-288.

Siekevitz, P., and G. E. Palade 1959 A cytochemical study on the pancreas of the guinea pig. IV. Chemical and metabolic investigation of the ribonucleoprotein particles. J. Biophys. Biochem. Cytol., 5: 1-10.

Stevens, C. E., and C. P. Leblond 1953 Renewal of the mucous cells in the gastric mucosa of the rat. Anat. Rec., 115: 231-245.

Townsend, S. F. 1961 Regeneration of gastric mucosa in rats. Am. J. Anat., 190: 133-147.

Vial, J. D., and H. Orreggo 1960 Electron microscope observations on the fine structure of parietal cells. J. Biophys. Biochem. Cytol., 7: 367-372.

Watson, M. L. 1958 Staining of tissue sections for electron microscopy with heavy metals. J. Biophys. Biochem. Cytol., 4: 475-478.

Zeigel, R. F., and A. J. Dalton 1962 Speculations based on the morphology of the Golgi systems in several types of protein-secreting cells. J. Cell Biol., 15: 45-54. 


\title{
Abbreviations
}

\author{
A, Axon \\ AC, Argyrophilic cell \\ $B I$, Basal infolding \\ BM, Basement membrane \\ C, Canaliculus \\ CAP, Capillary \\ CC, Chief cell \\ $\mathrm{CE}$, Centriole \\ CI, Cisterna \\ D, Desmosome \\ DC, Dilated cisterna \\ E, Endothelial cell \\ ER, Endoplasmic reticulum
}

F, Fibrils

G, Golgi apparatus

GR, Granule

GV, Golgi vesicle

L, Lumen

M, Mitochondria

MNC, Mucous neck cell

MV, Microvillus

MVB, Multivesicular body

$\mathrm{N}$, Nucleus

$\mathrm{NC}$, Neurilemmal sheath cell

NU, Nucleolus

NPC, Neck parietal cell
$\mathrm{P}$, Plasmalemma

PC, Parietal cell

PV, Pinocytotic vesicle

R, Ribosome

RER, Rough surfaced endoplasmic reticulum

SC, Surface cell

SER, Smooth surfaced endoplasmic reticulum

SG, Small granule

$\mathrm{V}$, Vacuole

ZO, Zonula occludens

All tissues illustrated were preserved in Palade's osmic acid fixative unless stated to the contrary.

\section{PLATE 1}

EXPLANATION OF FIGURES

2 Nondifferentiated cell. The cell is columnar. The nucleus $(\mathbf{N})$ is large, elongate, basally located and contains a small nucleolus (NU). The endoplasmic reticulum (RER) is sparse and cisternae are of irregular shape. There are many clusters of free ribosomes in the ground cytoplasm which is of low density. The Golgi apparatus (G) is located lateral to the nucleus. The apical plasmalemma (left) possesses short microvilli. $\times 9,900$.

3 Nondifferentiated cell. The lateral plasmalemma (P) is generally straight with few interdigitations with adjacent cells. The thin, amorphous basement membrane (BM) follows the basal contour of the cell. The nucleus $(\mathrm{N})$ is basal. The endoplasmic reticulum (RER) is poorly developed and is found throughout the cell. Portions of its external surface possess attached ribosomes; elsewhere it is smooth. A multitude of free ribosomes ( $R$ ) are arranged in clusters. The cisternae (Cr) contain a material of low electron density. The elongated or oval mitochondria (M) have transversely oriented cristae. The Golgi apparatus (G) is extensive and consists of flattened saccules with little dilation; small, dense vesicles; and a few larger vacuoles of irregular form. $\times 17,800$. 

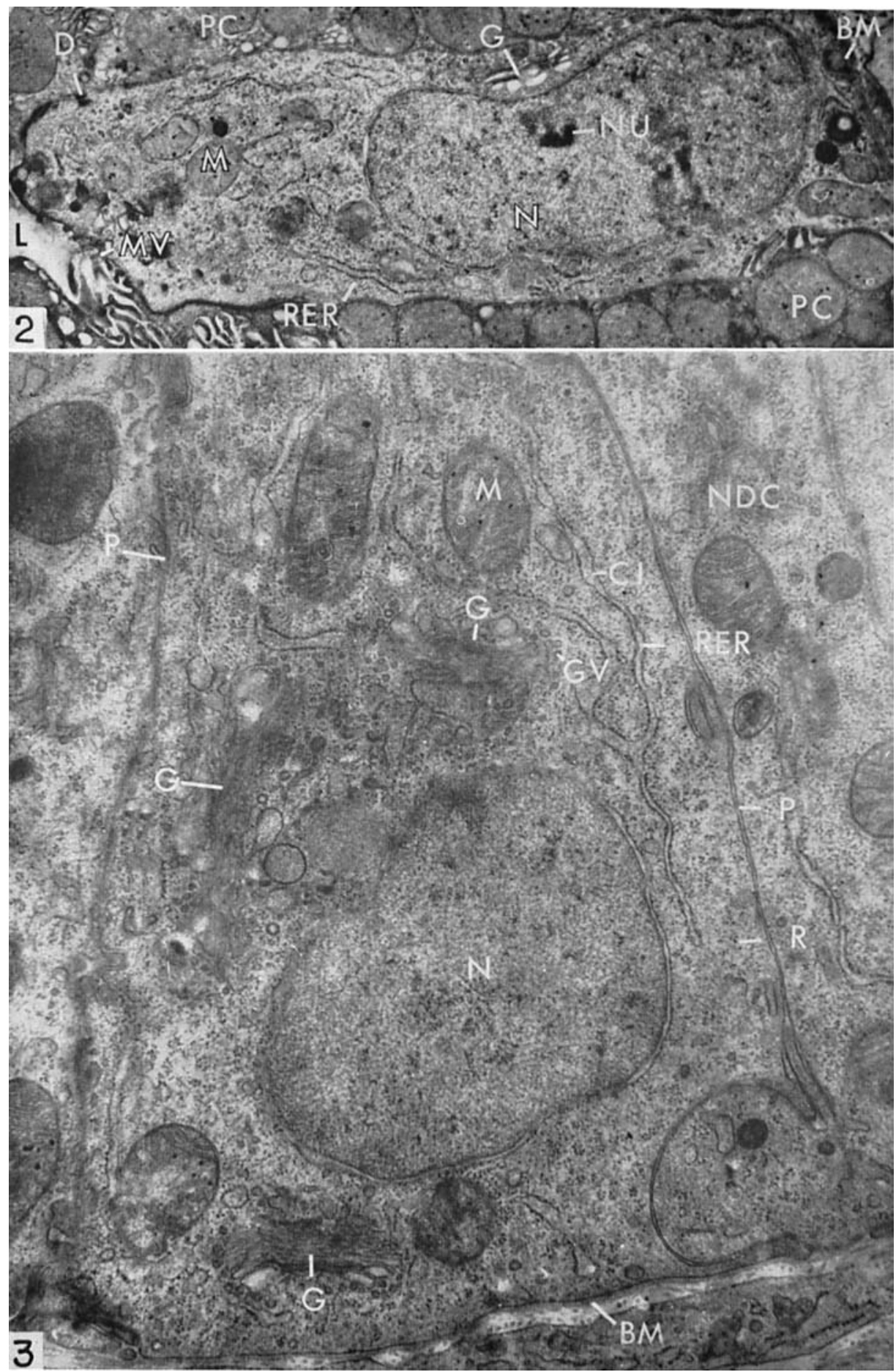
PLATE 2

EXPLANATION OF FIGURE

4 Surface mucous cell from the wall of a gastric pit. The cell is high columnar, the lumen ( $\mathrm{L}$ ) of the pit being at the upper end. The oval nucleus $(N)$ is basal and contains a nucleolus (NU). The lateral plasmalemma (P) is tortuous and interdigitated with adjacent cells. Desmosomes (D) are occasionally present. The apical plasmalemma is flat and generally lacking in microvilli. The supranuclear Golgi apparatus $(\mathbf{G})$ is large. Its stacks of three or more flattened saccules are peripherally oriented with rare mild dilation of the external ones (DC). The flattened saccules show unusually intense electron density. Many small vesicles are found internal to the saccules. The roughsurfaced endoplasmic reticulum (RER) is more extensively developed than in the nondifferentiated cell but is similar in having many areas with no attached ribosomes. The irregularly shaped cisternae of the endoplasmic reticulum contain material of low electron density. Free ribosomes are dispersed in the ground substance, often being arranged in clusters. Oval, dense, mucous granules (GR) occur within the Golgi apparatus and appear to move into the apical region where they become densely packed and more discoidal beneath the surface membrane. The mitochondria are elongate, pleomorphic, and contain numerous, wavy, transversely oriented cristae and a few dense granules. Cytoplasmic fibrils (F) abound in the apical cytoplasm. $\times 15,000$. 


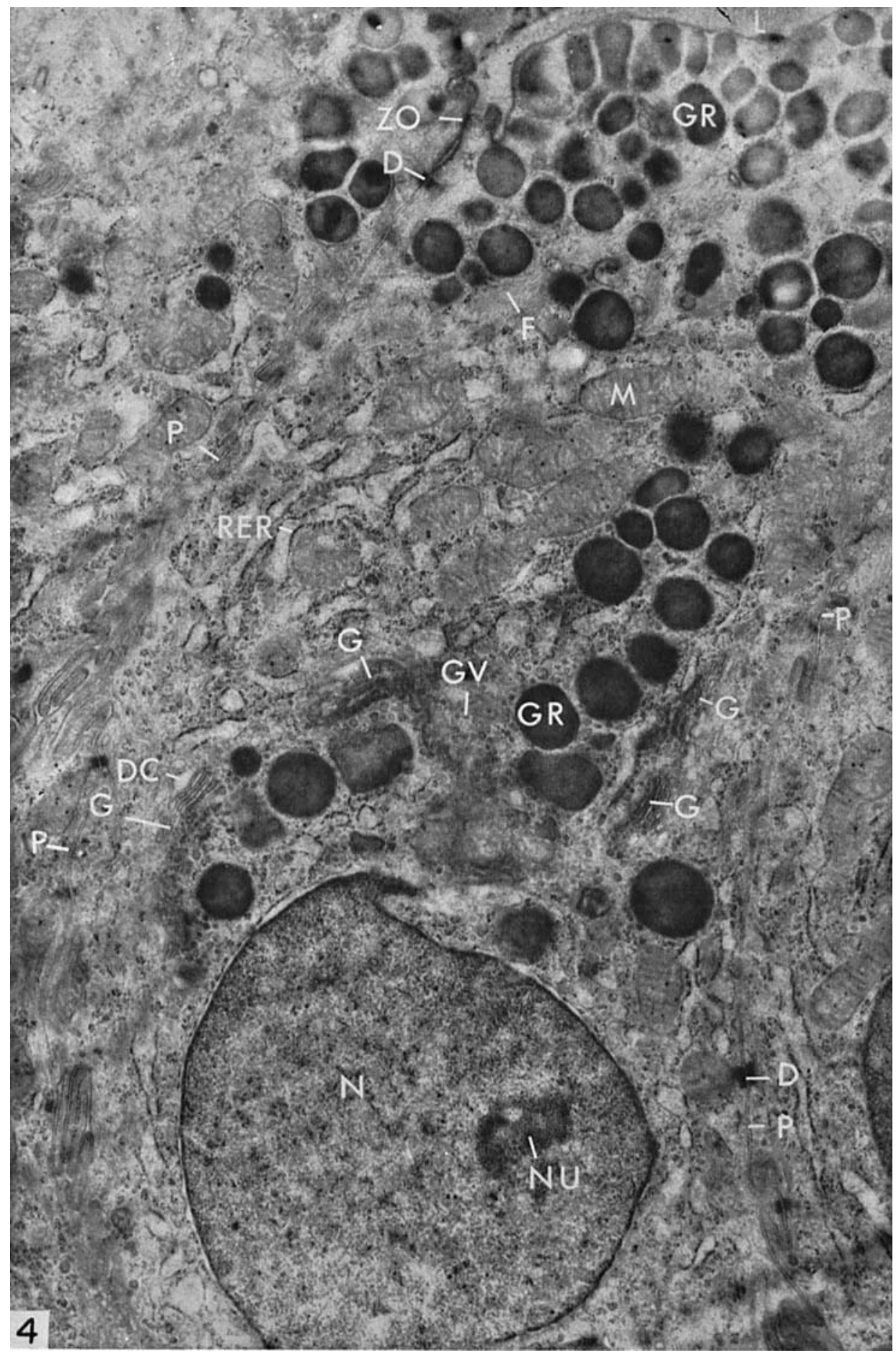


PLATE 3

\section{EXPLANATION OF FIGURE}

5 Immature surface cells and neck parietal cell. At the left and right of the glandular lumen (L) are portions of three columnar immature surface cells (SC). The plasmalemmas (P) of contiguous surface cells are deeply interdigitated. The nucleus $(N)$ is of irregular shape and its nucleoplasm is of low density. Rough-surfaced endoplasmic reticulum (RER) is poorly developed. There is a multitude of free ribosomes. Mitochondria (M) are of irregular shape, have cristae of variable form and density, and are much smaller than the mitochondria of neighboring neck parietal cells (NPC). The apical cytoplasm contains mucous granules (GR) of high electron density. The Golgi apparatus $(G)$ is lateral to the nucleus.

The neck parietal cell (NPC) is pyramidal and contains numerous pleomorphic mitochondria $(M)$ with densely arranged cristae. Microvilli (MV), both at the apex and within canaliculi (C), are densely packed and bulbous. Cytoplasmic vacuoles are of irregular shape and distributed predominantly in the apex of the cell and in the vicinity of canaliculi. The Golgi apparatus (G) is located laterally. The plasmalemma (P) is somewhat folded laterally and basally. $\times 9,900$. 


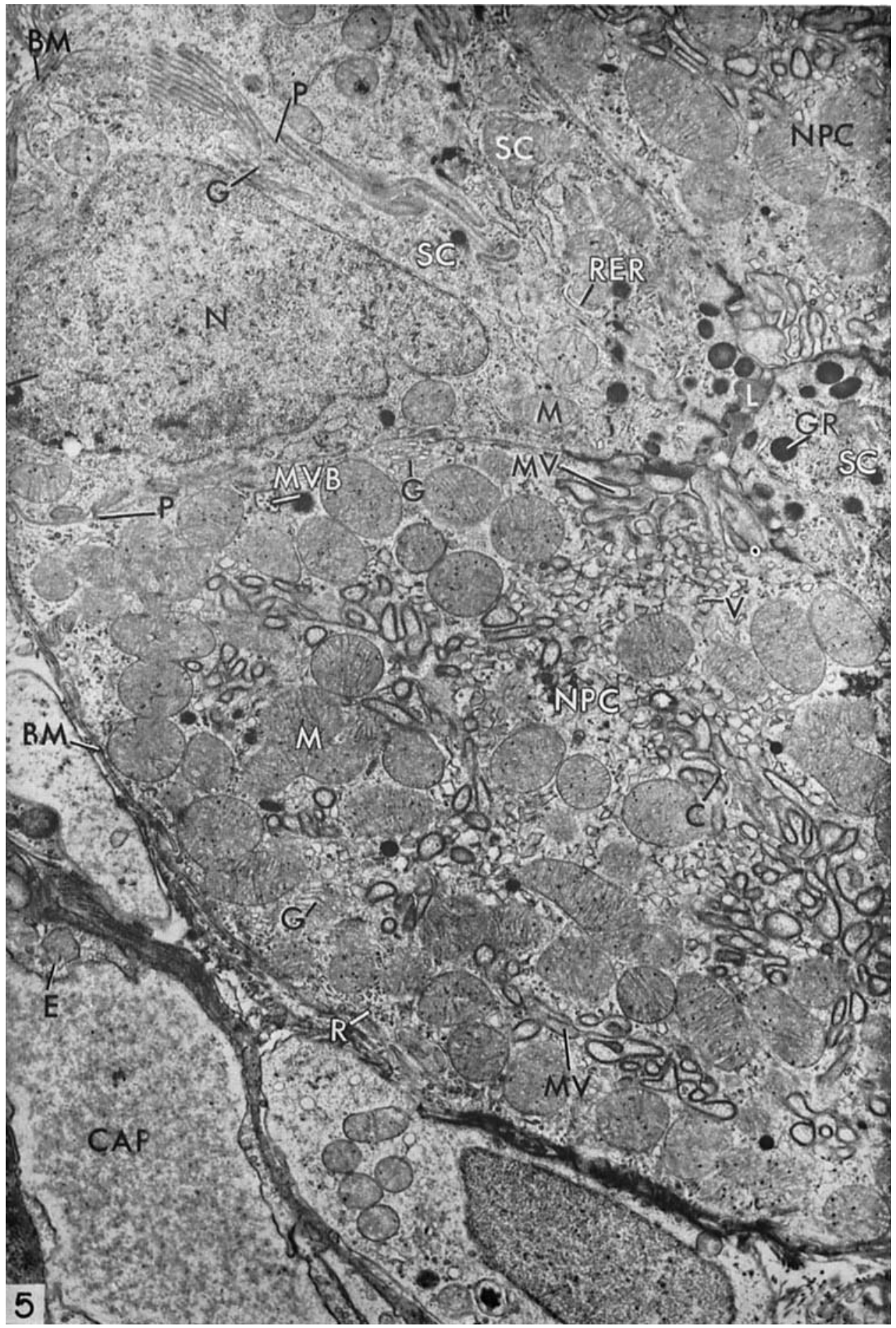




\section{PLATE 4}

\section{EXPLANATION OF FIGURES}

6 Mucous neck cell. The cell is low columnar and somewhat constricted basally. The nucleus $(N)$ is basal. The lateral plasmalemma $(P)$ is tortuous and interdigitates with adjacent cells. Occasional desmosomes (D) are present. The undulating apical plasmalemma is without microvilli except laterally near the junction with adjacent cells. Basal cytoplasm is sparse, and the rough-surfaced endoplasmic reticulum (RER) is poorly developed. Free ribosomes (R) are numerous. The apical cytoplasm is filled with large, round granules of mucoprotein of moderate electron density. $\times 12,300$.

7 Mucous neck cell. The supranuclear region reveals an extensive Golgi apparatus (G) composed of flattened saccules, numerous dilated extermal saccules (DC) and dense vesicles (GV). The supranuclear region is packed with mucoprotein granules (GR); a limiting membrane (arrow) is sharply defined on the side of some granules near the Golgi apparatus. Some Golgi vesicles (*) appear to be in direct contact with a secretory granule. Ribosomes are attached to much but not all of the external surface of the endoplasmic reticulum. Free ribosomes are frequent. Mitochondria (M) are located laterally. $\times 14,600$. 

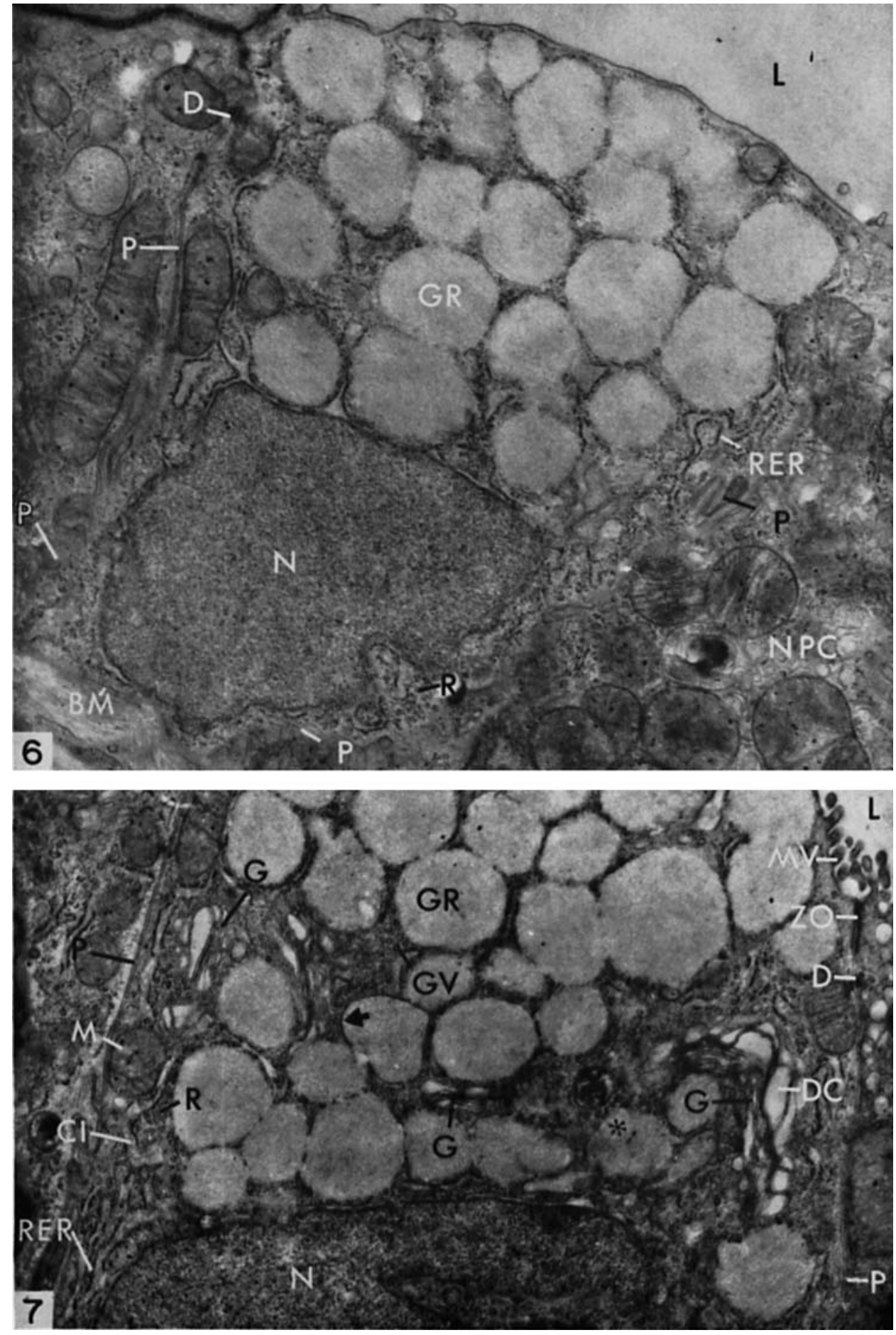


\section{PLATE 5}

EXPLANATION OF FIGURE

8 Immature mucous neck cell. This columnar cell is located in the neck region adjacent to neck parietal cells (NPC). The nucleus (N) is large, oval, basal, and has a dense central nucleolus (NU). The lateral plasmalemma $(P)$ is generally straight with only a few interdigitations with adjacent parietal cells. A desmosome (D) appears apically. The apical cytoplasm contains a few secretory granules (GR) of moderate density. A centriole (CE) with attached cilium is located in the supranuclear area. The rough-surfaced endoplasmic reticulum ( $R E R$ ) is limited in extent, and encompasses cisternae of irregular shape. There are numerous free ribosomes. The mitochondria (M) are oval and possess few cristae. $\times 18,900$. 


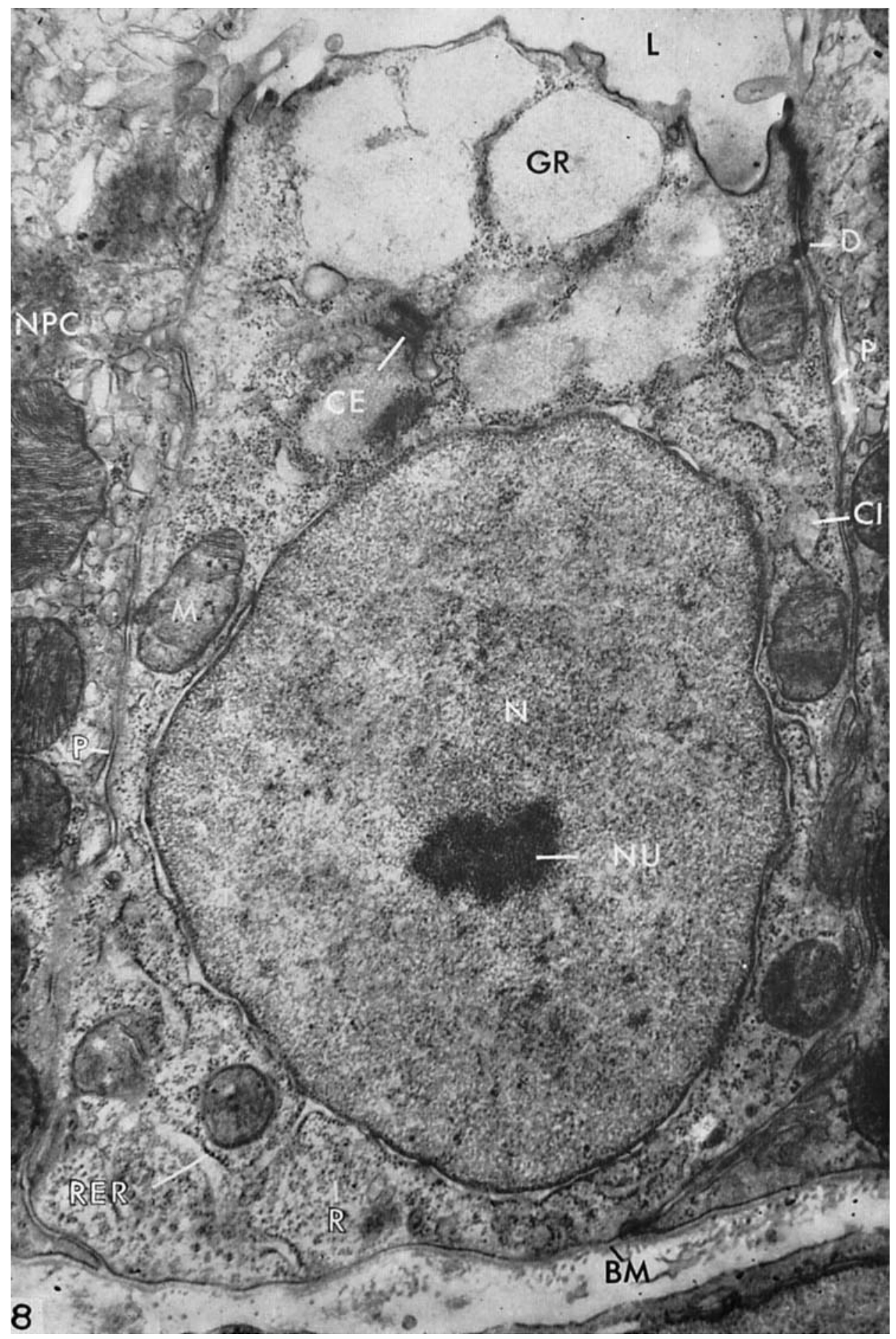


PLATE 6

EXPLANATION OF FIGURES

9 Neck parietal cell. The cell is pyramidal. The nucleus ( $N$ ) is basal and has a nucleoplasm of low density. Cytoplasmic vacuoles are almost totally absent. Intracellular canaliculi (C) extend deep into the cell and are occluded by long microvilli (MV). Mitochondria (M) are pleomorphic, of variable size, and contain many cristae. Endoplasmic reticulum (RER) is exceedingly sparse. Rosettes of ribosomes are randomly distributed throughout the cytoplasm. Several dense mucous granules (GR) appear in the apical cytoplasm. $\times 8,500$.

10 Neck parietal cell. The tongue-like apical cytoplasm projects into the glandular lumen (L) and contains densely packed vacuoles, many of which seem to be collapsed. An intracellular canaliculus (C) is partially occluded by long, thick microvilli (MV). Several multivesicular bodies (MVB) and mucous granules (GR) are present. $\times 14,600$.

The Golgi apparatus (insert) consists chiefly of a few small vesicles and flattened saccules with minimal dilation. $\times 12,500$. 

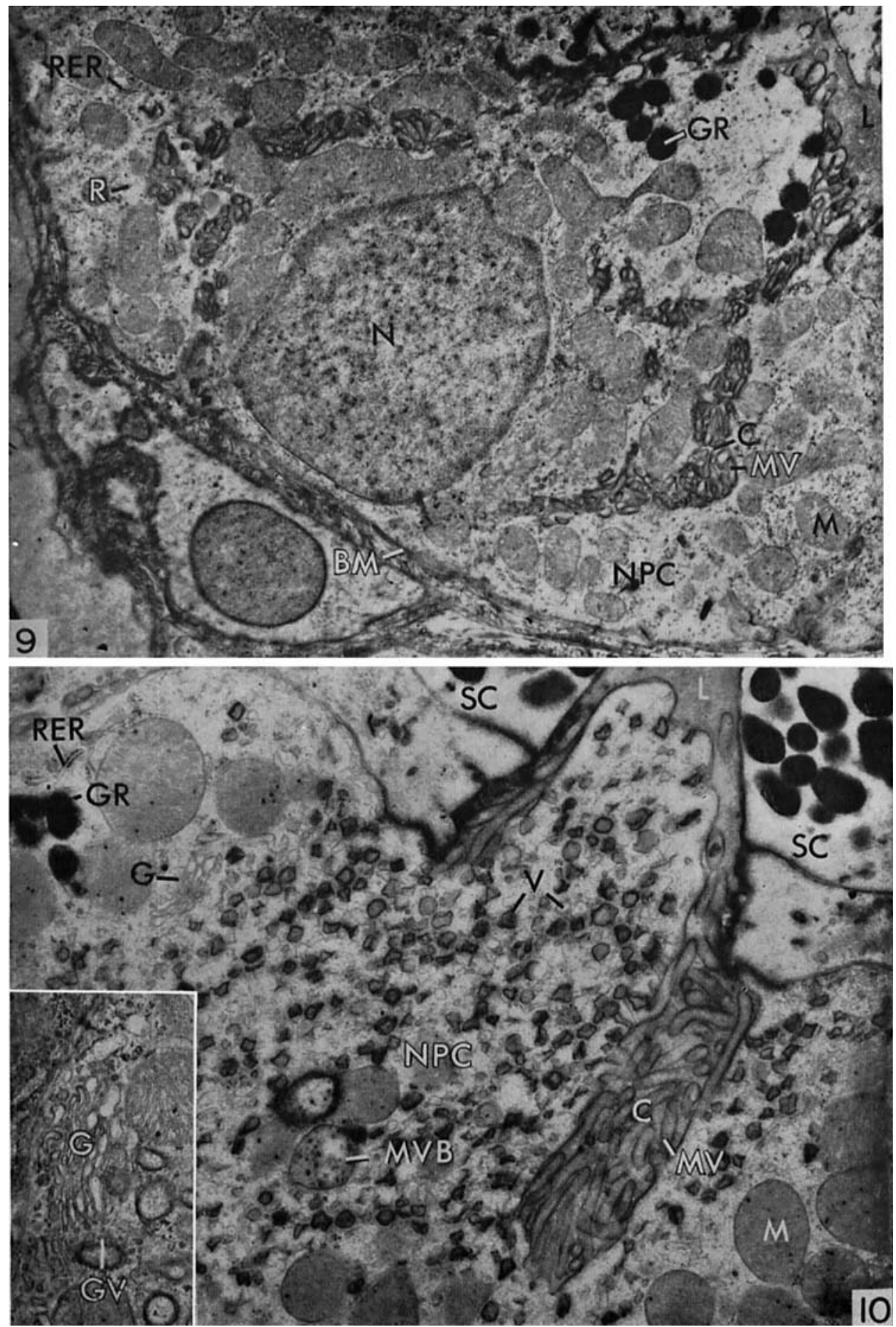


\section{PLATE 7}

\section{EXPLANATION OF FIGURE}

11 Chief cell, nonhypophysectomized rat. The cell contains numerous zymogenic granules (GR) of varied size, shape and density. Occasional small dense granules (SG), which resemble similar bodies located in the neighborhood of the Golgi apparatus, occur in the apical cytoplasm. The Golgi apparatus ( $G$ ) is supranuclear and widespread. It consists primarily of flattened saccules whose cisternae show varying degrees of dilation (DC). Small Golgi vesicles (GV) are numerous. Several short, blunt microvilli (MV) project from the apical plasmalemma. The oval nucleus $(N)$ is surrounded by an extensive ergastoplasm consisting of well-organized rough-surfaced endoplasmic reticulum (RER), cisternae of fairly uniform caliber, many free ribosomes and rather dense intervening ground cytoplasm. $\times 15,000$. 


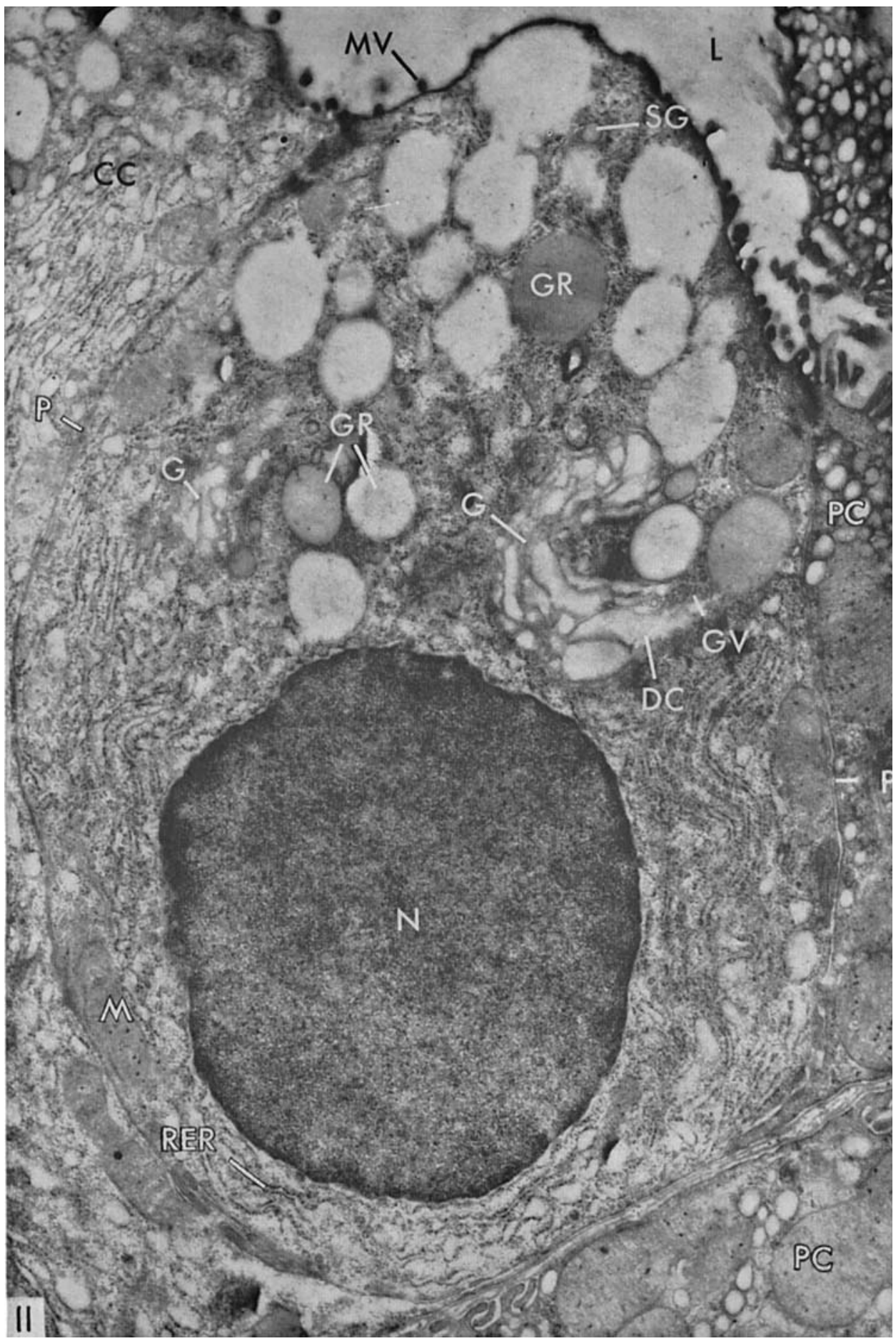


PLATE 8

EXPLANATION OF FIGURES

12 Chief cell, 74 days after hypophysectomy. The cell is small with a flat apical surface and few microvilli. Ergastoplasm is reduced in amount, the rough-surfaced endoplasmic reticulum (RER) being sparse and of irregular contour, free ribosomes are depleted and the ground cytoplasm appears hydropic. The Golgi apparatus (G) is compact. Zymogenic granules (GR) are scarce and difficult to identify. Several small granules (SG) are observed just beneath the apical plasmalemma. $\times 15,000$.

13 Perinuclear area of a chief cell, 74 days after hypophysectomy. Numerous polyribosomes (arrows) are demonstrated. A few cisternae of the rough-surfaced endoplasmic reticulum (RER) are observed at the periphery of the micrograph. $\times 28,600$. 

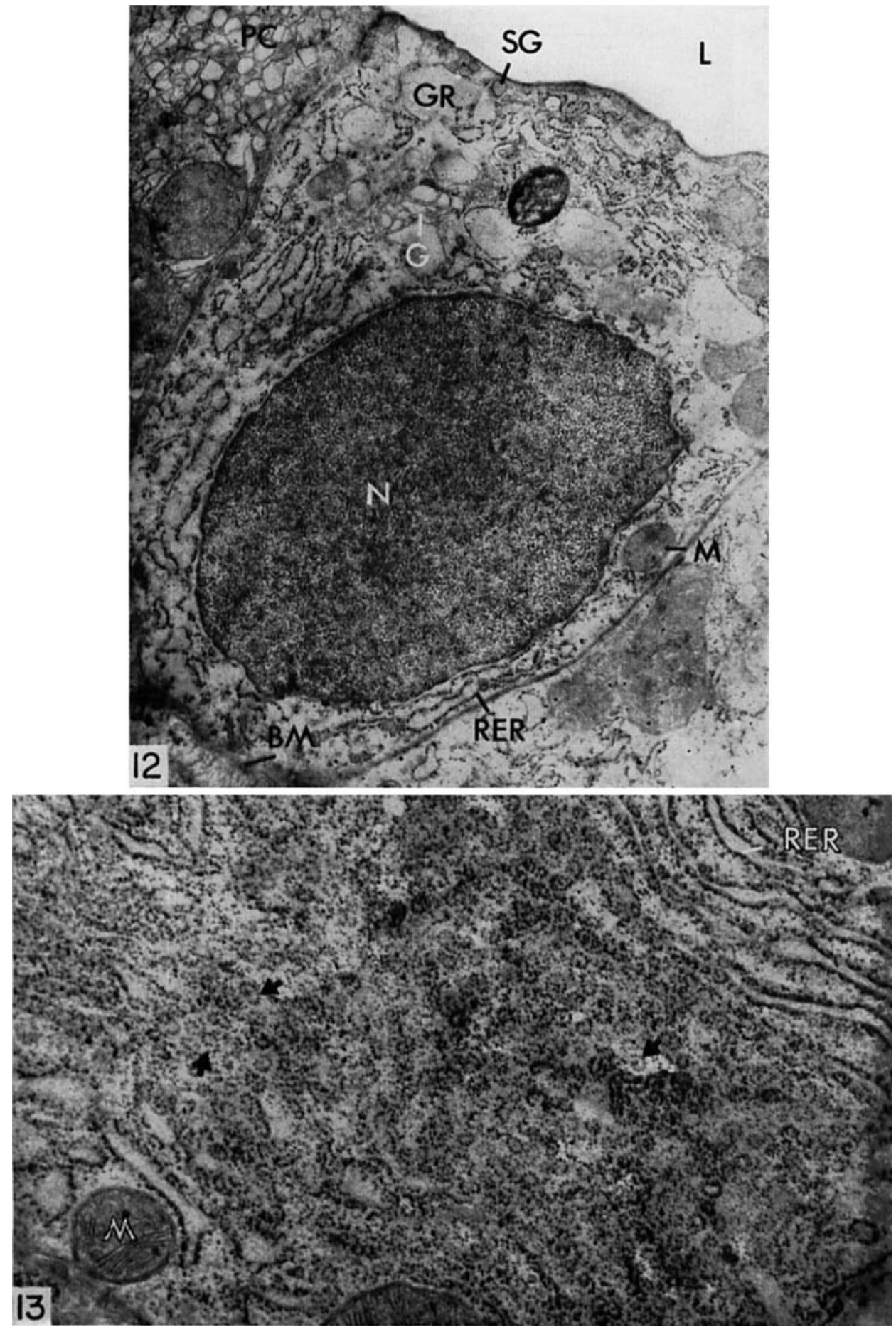
PLATE 9

EXPLANATYON OF FIGURES

14 Apical region of a chief cell from a nonhypophysectomized art. Several round or oval zymogenic granules (GR) have accumulated in the apical region causing the surface to bulge into the glandular lumen (L). One granule approximates the apical plasmalemma. The Golgi apparatus (G) is well-developed and broadly expanded. Several small, dense granules (SG), extensive rough-surfaced endoplasmic reticulum (RER) and many free ribosomes are present also. $\times 26,000$.

15 Apical region of a chief cell, 74 days after hypophysectomy. Zymogenic granules (GR) are sparse and do not appear in the most superficial zone of cytoplasm. Small granules (SG) are numerous and appear in intermediate sizes down to that of the Golgi vesicle (GV). A narrow zone free of organelles lies just beneath the apical plasmalemma. Rough-surfaced endoplasmic reticulum (RER) is poorly organized and the ground cytoplasm is of low density. Several apical microvilli project into the lumen (L). $\times 26,000$. 


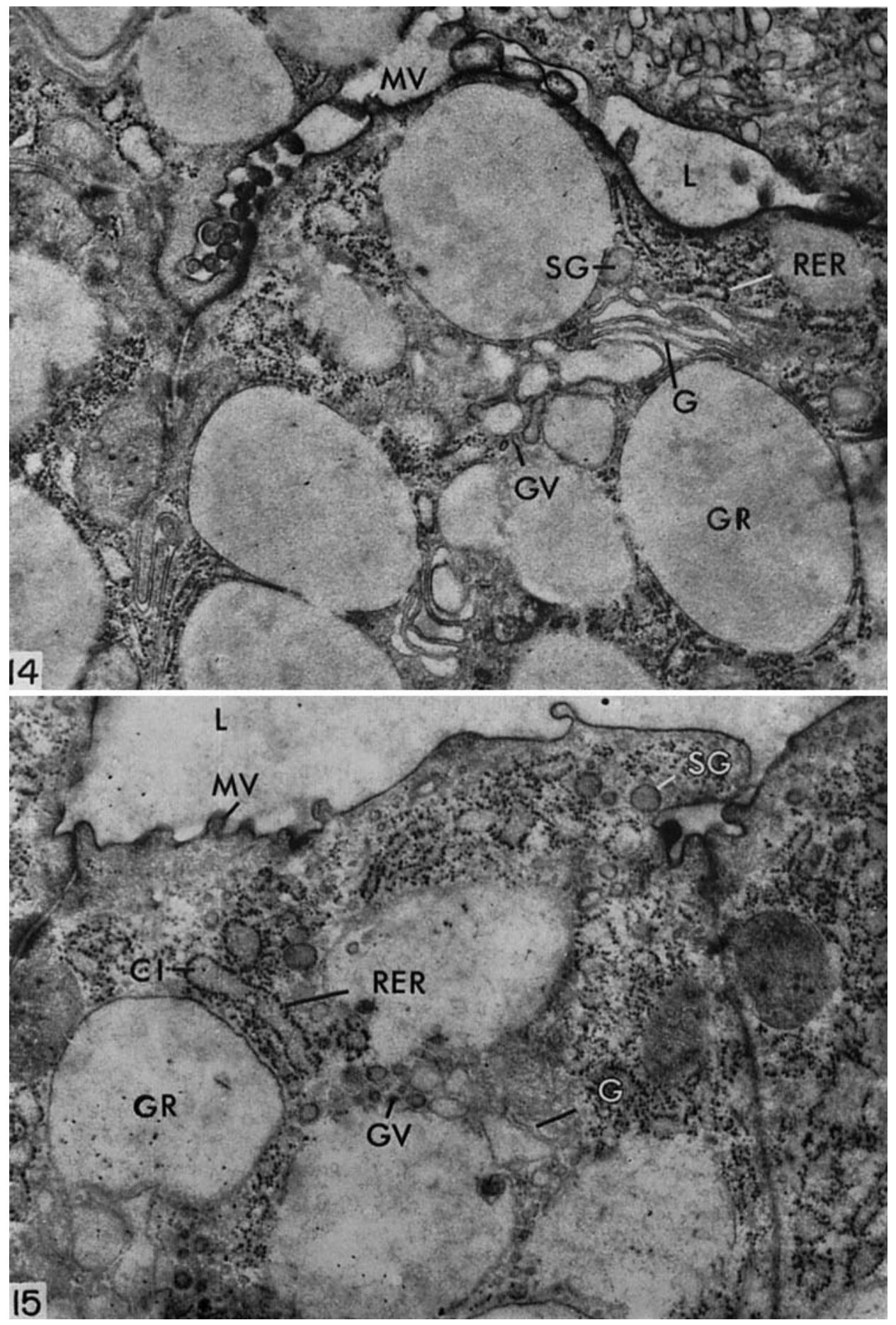


PLATE 10

EXPLANATION OF FIGURES

16 Basal portion of a chief cell from a nonhypophysectomized rat. The ergastoplasm is well-organized. Free and attached ribosomes are numerous. Cisternae (CI) contain electron dense material. Ground cytoplasm between cisternae is fairly dense. $\times 41,800$.

A mitochondrion (insert) of the chief cell illustrating its typical shape and position near the plasmalemma. Several transversely oriented cristae span the entire width of the mitochondrion, which exhibits a dense, granular matrix with several intramitochondrial granules. $\times 41,800$.

17 Basal region of a chief cell 58 days after hypophysectomy. This micrograph illustrates in mild form the changes which followed hypophysectomy. There may be some reduction in concentration of ribosomes but most striking is the reduced density of the ground cytoplasm which appears hydropic. $\times 41,600$.

A mitochondrion (insert) from a hypophysectomized rat has transversely oriented cristae, a dense granular matrix, and intramitochondrial granules. $\times 41,800$. 


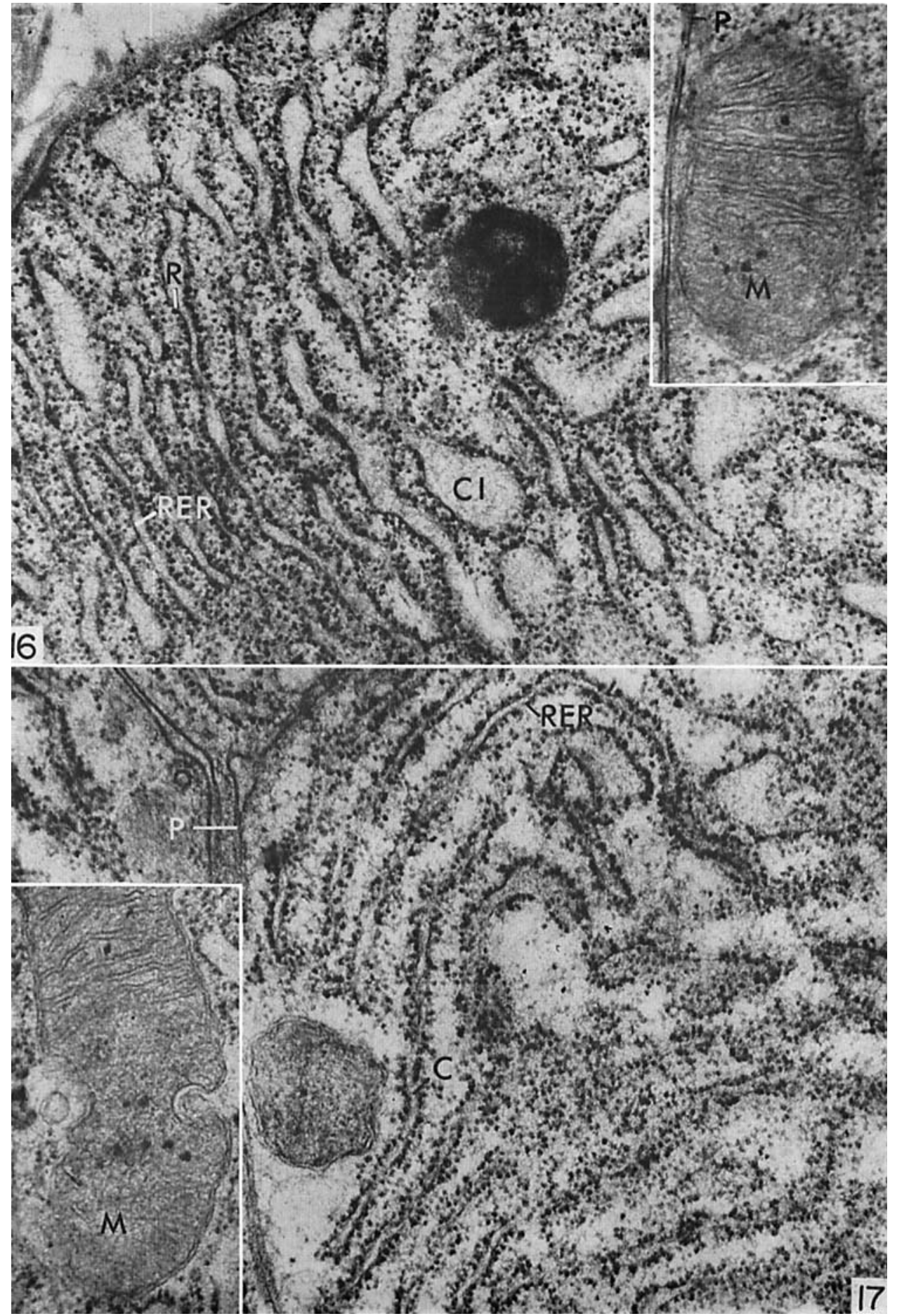


PLATE 11

\section{EXPLANATION OF FIGURES}

18 Basal area of a chief cell from a nonhypophysectomized rat; Dalton's fixative. The ergastoplasm with its rough-surfaced endoplasmic reticulum (RER), dense intervening ground cytoplasm, free and attached ribosomes, is compactly arranged. $\times 21,600$.

19 Basal area of a chief cell, 74 days after hypophysectomy; Dalton's fixative. Compared with figure 18, the amount of ergastoplasm is reduced, the rough-surfaced endoplasmic reticulum (RER) is less extensive, ribosomes are fewer, and ground cytoplasm is less dense. Observe the excellent fixation of the parietal cell (PC) on the right. $\times 21,600$. 

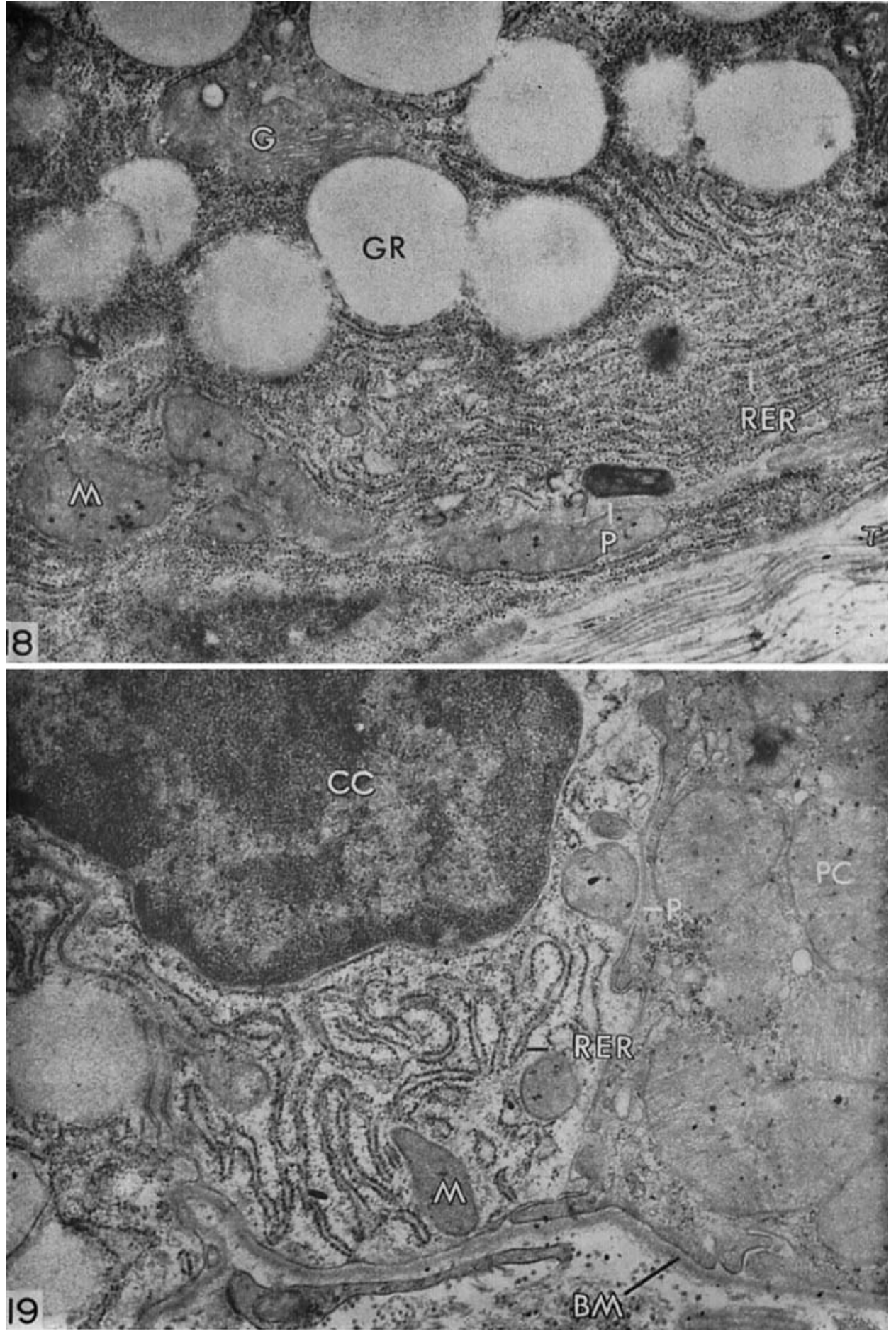
PLATE 12

EXPLANATION OF FIGURES

20 Golgi apparatus of a chief cell from a nonhypophysectomized rat. The peripheral limits of the Golgi apparatus (G) are indicated by arrows. It is spread extensively through the supranuclear region of the cell. The Golgi apparatus consists of flattened saccules with considerably dilated cisternae, small dense Golgi vesicles (GV), and some vacuoles (V). Large secretory granules (GR) are dispersed through the Golgi region. A gradation in size and density can be observed between the small Golgi vesicle (GV) and the small granule (SG). The Golgi apparatus encompasses cytoplasm containing roughsurfaced endoplasmic reticulum and free ribosomes. $\times 15,400$.

21 Golgi apparatus in two chief cells, 120 days after hypophysectomy. The Golgi apparatus is outlined by arrows. As compared with figure 20 the size of the Golgi apparatus is reduced and its cisternae (CI) are less dilated. The large vacuoles may be secretory granules in an early stage of formation. Golgi vesicles are numerous and compactly arranged. $\times 15,400$. 


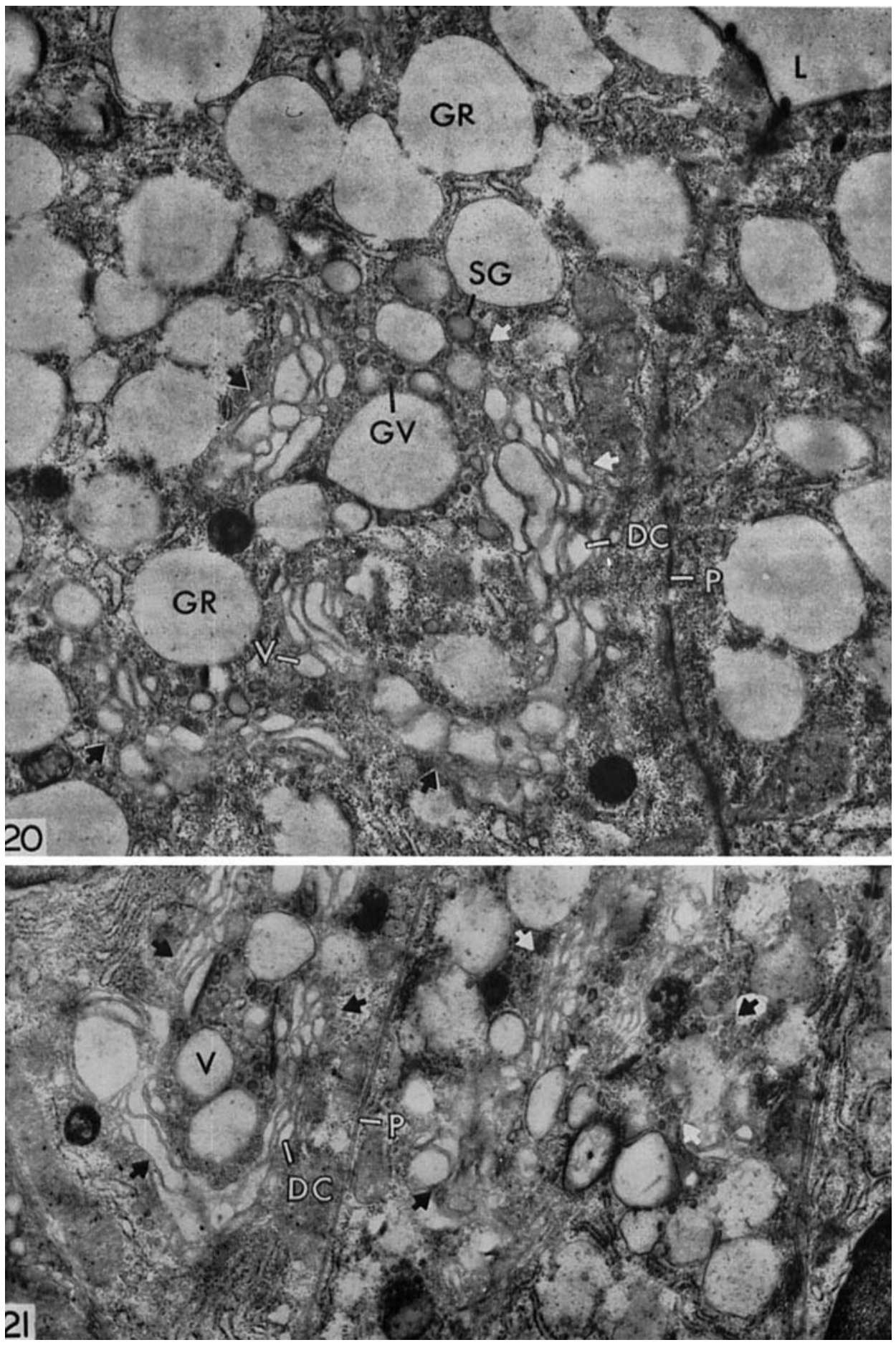


PLATE 13

EXPLANATION OF FIGURES

22 Basal region of two parietal cells, nonhypophysectomized rat. The cells rest against the basement membrane (BM). Numerous basal infoldings (BI) are evident. Canaliculi (C) are wide. Microvilli (MV) are long and of uniform caliber. Cytoplasmic vacuoles (V) border the canaliculi. Mitochondria (M) contain many transversely oriented cristae and a dense matrix $\times 41,600$.

23 Basal region of a parietal cell, 196 days after hypophysectomy. The maximal width of canaliculi (C) is less than in figure 22. Microvilli (MV) are distorted and of irregular caliber and shape. Cytoplasmic vacuoles (V), mitochondria, and ribosomes appear unchanged. $\times 41,600$. 

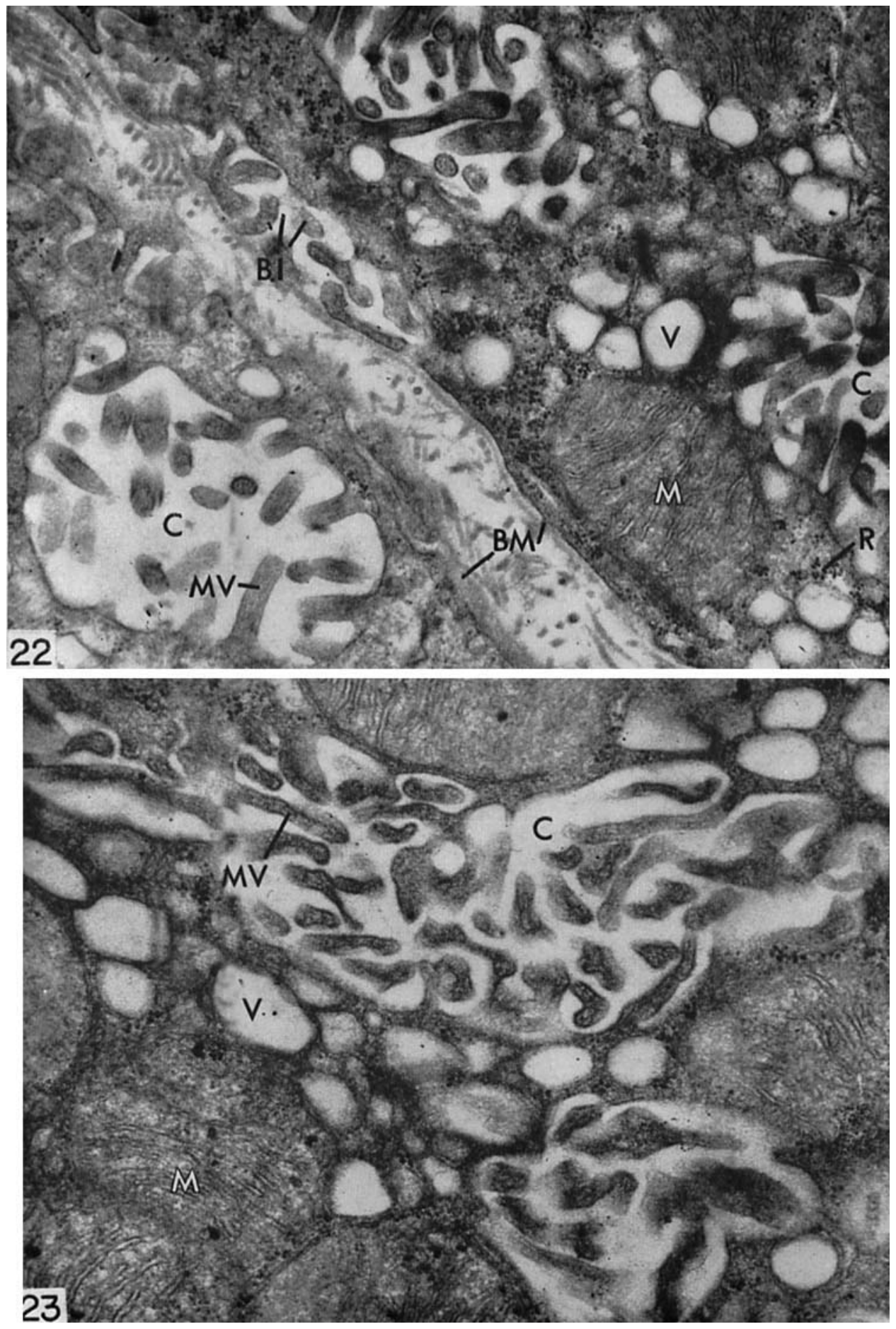